\title{
PALAVRAS LIDAS
}

\section{WORDS READ}

\section{PALABRAS LEÍDAS}

Camila Santos Pereira ${ }^{1}$

RESUMO

Números correm fora do controle. Estatísticas de mortes evitáveis crescem, em um ritmo frenético, descontrolado, mas prenunciável, e denunciam o abandono, a precarização. O texto apresenta uma reflexão sobre leituras, entendendo as palavras como as melhores e piores companhias. Tratamos das palavras que caminham juntas com o estado de (sobre)vivência, no Brasil, durante a pandemia do Covid-19, cercando sobretudo pessoas negras e/ou LGBTI+. Mergulhar na literatura equivale a entrar em outra dimensão, na qual a realidade brutal, vivida diariamente, não nos faça reféns. Podemos confrontar a desumanidade, em outras magnitudes, portanto, descrevendo as relações complexas que o ato de ler nos proporciona. Da escrevivência nos servimos e compartilhamos seu feito em quem escrevive.

PALAVRAS-CHAVE: Leitura. Pandemia. Escrevivência.

\section{ABSTRACT}

Numbers run out of control. Statistics of preventable deaths are growing, in a frantic, uncontrolled, but predictable rhythm, and denounce abandonment, precariousness. The text presents a reflection on readings, understanding the words as the best and worst companions. We deal with the words that go together with the state of struggle for survival, in Brazil during the Covid-19 pandemic, mainly surrounding black people and/or LGBTI+. Diving into literature is equivalent to entering another dimension, in which the brutal reality, experienced daily, does not take us hostage. We can confront inhumanity, in other magnitudes; therefore, describing the complex relationships that the act of reading provides us. From the escrevivência, we use and share its doing in those who write.

KEYWORDS: Reading. Pandemic. Escrevivência.

\section{RESUMEN}

Los números se salen de control. Crecen las estadísticas de muertes evitables, a un ritmo frenético, descontrolado, pero predecible, y denuncian abandono, precariedad. El texto presenta una reflexión sobre las lecturas, entendiendo las palabras como las mejores y las peores compañeras. Nos ocupamos de las palabras que

Submetido em: 30/04/2021 - Aceito em: 30/04/2021 - Publicado em: 12/07/2021

1 Mestranda em Educação pela Universidade do Estado do Rio de Janeiro (ProPed/UERJ). Especialista em Orientação Educacional (UNIASSELVI). Integrante do geni - estudos em gênero e sexualidade e do Grupo de Estudos em Educação e Transgressão (GEETRANS). Licenciada em Ciências Sociais (UFRGS). 
van de la mano del estado de supervivencia, en Brasil, durante la pandemia de Covid-19, principalmente en torno a personas negras y / o LGBTI+. Bucear en la literatura equivale a entrar en otra dimensión, en la que la realidad brutal, vivida a diario, no nos toma como rehenes. Podemos afrontar la inhumanidad, en otras magnitudes; por tanto, describiendo las complejas relaciones que nos brinda el acto de leer. Desde la escrevivencia utilizamos y compartimos su hazaña en quienes escriben.

PALABRAS CLAVE: Lectura. Pandemia. Escrevivência.

Números correm fora do controle. As mãos malfeitoras, higienizadas com álcool em gel, dotadas de poder, os ignoram. No entanto, eles perseguem, dilaceram, reduzem vidas e histórias. Denunciam o abandono, a precarização. Os algoritmos crescem todos os dias, em um ritmo frenético, descontrolado, mas prenunciável. Em telas grandes ou pequenas, no virtual ou no papel, eles estão por toda parte. Sondam, esperam respostas, quem sabe? Permaneço confinada em meio a saídas corriqueiras de amparo necessário. Fujo deles. Minha fuga encontro na relação cheia de encruzilhadas com as palavras em um túnel antigo e inexplorado.

As palavras, sim, são elas minhas melhores e piores companhias. Quando desenhadas em uma folha de papel me remetem a um tempo não tão distante. O costume de desenhá-las com lápis, lapiseira ou caneta colorida com perfume de laranja, integram uma época nostálgica. Naquele tempo, não tínhamos grandes preocupações de uma invasão cibernética e compartilhamento generalizado, nem eu tinha a noção do alcance de seus domínios. As borrachas me ajudavam a reescrever, não sequestravam meus rastros; ainda era possível enxergar minhas pegadas titubeantes no papel. Hoje utilizo um teclado que me trai, lacunas e comandos novos, movimentos repetidos e internalizados. Do mesmo modo, uma tela de vidro escura e fria, que cabe na palma da mão, quando acionada, ilumina e cativa uma visão faminta. Meus neologismos cheios de carinho e espirituosidade são endereçados para quem gosto e tenho afeição. Esse é o dispositivo mais desobediente. Quando tento pedir desculpas, o reflexo me interroga e distrai. Figurinhas trocadas provocam risadas cúmplices. Assim, sigo brincando com o fazer palavras. (Re)aprendo, jogo, me emociono, fico triste, tento consolar, teorizo, cometo erros, apago e escrevo de novo. Elas também me castigam, somem quando mais preciso, se esquivam de forma rude e seca.

Nem sempre elas são minhas, as palavras. Aliás, estou em um relacionamento mais intenso do que nunca com as palavras das outras pessoas que escrevem. Uma relação aberta, de muito respeito e diálogo, com alguns rompimentos no caminho e conciliações calorosas. Nas cartas que recebo, nas peças, nos contos, na poesia, nas séries, nos filmes, nas notícias, são realmente companheiras fiéis. Nesses tempos pandêmicos, as palavras, com as quais pude passear de braços dados sem sair de casa, me contaram sobre as aventuras de um tatu muito tímido que tinha o sonho de ver o mar; do tombo da Eduarda, na frente de sua ex-namorada, 
que lhe rendeu um grande roxo na perna; de um encontro tórrido entre um sargento e um moço jovem e acanhado; da mulher que não conseguia lembrar a cor dos olhos de sua mãe. Elas me contam mais um dos milhares de significados do amor, inventados por pessoas apaixonadas e/ou céticas. Elas me contaram que o país enfrenta uma falta de abastecimento de humanidade. Temos dois inimigos: um invisível e o outro com a habilidade questionável de utilizar uma máscara cirúrgica. O ódio e a hostilidade às vidas resistentes, sobretudo de pessoas negras e LGBTI+, obrigam-nos a enfrentar mais um cenário de sucateamento, e (sobre)viver passando por cima dos ataques e da falta de vacina para as pessoas que mais precisam. Os livros de História, de maneira tímida e silenciosa, pronunciaram esse estado de iniquidades, que dura mais de quinhentos anos. Não é surpresa, é criminoso.

Reencontro e faço as pazes com as palavras. Companheiras que me traduzem, são leais e arteiras. Sem elas não haveria a literatura, que de algum modo, nos salva. Sem elas não haveria este texto. Como diria Conceição Evaristo, a escrevivência serve para a gente pensar. Enfim, nessas memórias do cotidiano, nossas palavras pensadas, sentidas, de ordem e/ou em desordem, lidas, escritas, bem como os palavrões e as que saem em alto volume das gargantas aflitas, precisam escapar, para que possamos nos libertar.

\section{REFERÊNCIAS}

ABREU, Caio Fernando. Morangos mofados. São Paulo: Companhia das letras, 2019.

BOJUNGA, Lygia. O sofá estampado. Rio de Janeiro: Casa Lygia Bojunga, 2016.

EVARISTO, Conceição. Olhos d'água. Rio de Janeiro: Pallas Editora, 2016.

POLESSO, Natalia Borges. Amora. Porto Alegre: Editora Dublinense, 2016.

SANTANA, Tayrine; ZAPPAROLI, Alecsandra. Conceição Evaristo "a escrevivência serve também para as pessoas pensarem". Itaú Social. Disponível em:

$<$ www.itausocial.org.br/noticias/conceicao-evaristo-a-escrevivencia-serve-tambem-para-aspessoas-pensarem/>. Acesso em: 26 abr. 2021.

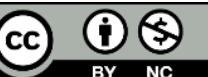

Este é um artigo de acesso aberto distribuído sob os termos da Licença Creative Commons Atribuição Não Comercial-Compartilha Igual (CC BYNC- 4.0), que permite uso, distribuição e reprodução para fins não comerciais, com a citação dos autores e da fonte original e sob a mesma licença. 